Original Scientific Article

\title{
EFFECT OF GUM ARABIC ON STALLION SPERM SURVIVAL DURING COLD STORAGE AND POST FREEZING
}

\author{
Mohamed Ali ${ }^{1}$, Musa M. Musa ${ }^{2}$,Sulaiman Alfadul², K. Al-Sobayel ${ }^{1}$ \\ ${ }^{1}$ Animal Production and Breeding, Faculty of Agriculture and Veterinary Medicine, \\ Qassim University, Qassim State, Saudi Arabia \\ ${ }^{2}$ Department of Chemistry, King Fahd University of Petroleum \& Minerals \\ Dhahran 31261, Saudi Arabia \\ ${ }^{3}$ King Abdulaziz City for Science and Technology P.O.Box 6086, \\ Riyadh 11442, Saudi Arabia
}

Received 8 April 2016; Received in revised form 13 September 2017; Accepted 29 September 2017

\begin{abstract}
This study is aimed at investigating effects of supplementation of stallion' semen extender with various concentrations of Gum Arabic (GA) versus egg yolk (EY) on viscosity, sperm motility and survival during cooling and freezing. Physical sperm characteristics; i.e. curvilinear velocity (VCL), straight line velocity (VSL), average path velocity (VAP), linearity (LIN) and straightness index (STR) were evaluated. Based on the sperm velocity (velocity of the average path), individual spermatozoons were classified into two major groups; i.e., progressively motile ( $>45 \mu \mathrm{m} / \mathrm{sec})$ and immotile $(0-45 \mu \mathrm{m} / \mathrm{sec})$ spermatozoa. Addition of 3,9 or 15\% of GA to HF-20 extender resulted in linear decreases in VCL, VSL and VAP and a decrease in the percentage of progressively motile spermatozoa. Dilution of horse semen samples with high viscosityextenders (i.e., high percentage of GA) decreased the VCL, VSL and VAP in fresh and chilled semen. Freezing semen in high viscosity-extenders reduced percentage of progressively motile spermatozoa compared with those of low viscosity-extenders. In refrigerated and frozen semen samples, the extender containing $15 \%$ GA had detrimental effects on the percentage of progressively motile sperm cells and velocity of progressive motile sperm. Moreover, cooling sperm in extenders containing 9 or $15 \%$ of GA for 72 hours resulted in complete motility cessation. In conclusion, GA could replace EY in stallion semen extenders at a level of $3 \%$ to maintain the physical and biological characteristics of cold and frozen semen.
\end{abstract}

Key words: sperm characteristics, stallion, freezing, gum arabic, ISAS

\section{INTRODUCTION}

Egg yolk (EY) is a component of most semen extenders because it protects the sperm from thermal shock during cryopreservation (1). Despite the protective effect of EY, a few of its components are reported to have noxious effects on spermatozoa (2). Kampshmidt et al. (3) demonstrated that the granules found in EY reduce the respiration and

Corresponding author: Dr. Mohamed Ali, $\mathrm{PhD}$

E-mail address: alym@qu.edu.sa

Present address: Animal Production and Breeding, Faculty of Agriculture and Veterinary Medicine, Qassim University, Qassim State, Saudi Arabia Phone: +966163801073

Copyright: (C) 2017 Ali M. This is an open-access article published under the terms of the Creative Commons Attribution License which permits unrestricted use, distribution, and reproduction in any medium, provided the original author and source are credited.

Competing Interests: The authors have declared that no competing interests exist.

Available Online First: 19 November 2017

Published on: 15 March 2018

https://doi.org/10.1515/macvetrev-2017-0026 motility of spermatozoa in the bull. Furthermore, EY can be a source of bacterial contamination (4). However, results on immotile spermatozoa demonstrated that elevated concentrations of EY in semen extenders reduced accuracy of computer-detected spermatozoa via detection of false spermatozoa, which could actually be an EY particles or other debris. This needs more studies for other semen extender's constituents (5).

Computer-assisted methods have been employed for the examination of sperm motility, which can determine different types of sperm motility and velocity with high efficiency $(6,7)$. Furthermore, these methods could be used for routine diagnostic procedures at artificial insemination (AI) stations (7).

In the rat and hamster, immobilization of spermatozoa in the cauda epididymis could be partly due to high viscosity of the fluid in the 
epididymis (8). The viscosity of the semen extender was manipulated by the addition of carboxymethyl cellulose, methylcellulose, ficoll, or EY; and it was observed that the viscosity of the surrounding medium influenced the beating pattern of sperm flagella (9).

Gum Arabic (GA) might be used as extracellular cryoprotectant because it has the large structure of a polysaccharide. However, GA has never been reported in cryopreservation of stallion semen.

In the present study, GA was used in horse semen extenders as cold shock-protectant. GA is a sticky substance, and thus, this study sought to determine the influence of different concentrations of GA in extenders on stallion semen viscosity and sperm motility parameters, which were evaluated by a computer-assisted system.

\section{MATERIAL AND METHODS}

\section{Preparation of extenders}

Each $100 \mathrm{~mL}$ of the centrifugation solution was prepared by mixing glucose $(6.00 \mathrm{~g})$, EDTA $(0.37 \mathrm{~g})$, trisodium citrate $(0.37 \mathrm{~g})$, sodium bicarbonate $(1.20$ g), penicillin (100,000 IU) and streptomycin (80 $\mathrm{mg}$ ). Five extenders were used for this study; these are the HF-20 extender [EY (10 and $20 \%$ [v/v]) and GA (3, 9 and 15\% [wt/v])] containing glucose $(5.00 \mathrm{~g})$, lactose $(0.30 \mathrm{~g})$, raffinose $(0.30 \mathrm{~g})$, sodium citrate $(0.15 \mathrm{~g})$, sodium potassium tartrate $(0.05 \mathrm{~g})$, sodium phosphate $(0.05 \mathrm{~g})$, penicillin (100,000 IU) and streptomycin $(80 \mathrm{mg})$. In all solutions, distilled water was added to a final volume of $100 \mathrm{~mL}$. Gum Arabic was boiled for 30 minutes prior to use.

\section{Semen collection}

This study was conducted in the Agriculture and Veterinary Research Station, Qassim University, central region of Saudi Arabia. Three Arabian stallions were used in this study. Stallions were held in box stalls bedded with rice straw, fed oats and clover hay three times a day and water was freely available. Semen was collected using Missouri Artificial Vagina. Semen samples were filtered with sterile gauze immediately after collection. The gel fraction was then removed, and the remaining volume was measured in a graduated cylinder and transferred to a water bath adjusted at $37^{\circ} \mathrm{C}$. Quality test was performed for volume, color, $\mathrm{pH}$, viscosity, mass activity, individual progressive motility, concentration and live/dead ratio. Measurements of $\mathrm{pH}$ were adjusted using a
pH meter (Hanna, model HI-2212, Washington, USA). Viscosity measurements of the extender were determined by vibroviscometer (model SV10, Tokyo, Japan) at room temperature and at $4^{\circ} \mathrm{C}$. Osmolarity measurements of the extender were determined by Osmometer (model 800 CLG, SLAMED, Germany). Sperm motility and concentration were subjectively determined at $37{ }^{\circ} \mathrm{C}$ with a computer-assisted system (ISAS). Ejaculates with more than $60 \%$ progressively motile spermatozoa and a minimum sperm concentration of $200 \times 10^{6}$ sperm $/ \mathrm{mL}$ were selected for further study. Directly after collection, semen samples were diluted with a centrifugation solution at $37^{\circ} \mathrm{C}$ to approximately $100 \times 10^{6} \mathrm{sperm} / \mathrm{mL}$. Diluted semen samples were centrifuged at $800 \mathrm{Xg}$ for 10 min, and the supernatant containing the seminal plasma was removed. The sperm concentration in the resuspended pellet was determined using a Neubauer counting chamber (Kisker, Steinfurt, Germany), and fresh HF-20 extender (10) was added to a dilution of $150 \times 10^{6} \mathrm{sperm} / \mathrm{mL}$.

Fresh dilution with different concentrations of GA or $E Y$

Ejaculates (one from each of three stallions) were used. After seminal plasma removal by using centrifugation solution, the pellet was re-suspended with HF-20 extender. Five different HF-20 extenders [GA (3, 9, and 15\%) and EY (10 and 20\%)] were used at $\mathrm{pH} 6.9$ to dilute the semen. Computer-assisted system (ISAS) was conducted after dilution at $0,4,24,48,72$ and 96 hours of cooling.

Deep-freezing with extenders of various concentrations of $G A$ or $E Y$

After seminal plasma removal by using centrifugation solution, the pellet of two ejaculates from each of the three stallions was re-suspended with HF-20 extender containing GA (3, 9, and $15 \%)$ or EY $(10 \%)$ and glycerol $(3 \%)$; the final concentration of spermatozoa after dilution was about $150 \times 10^{6}$ sperm $/ \mathrm{mL}$. Each tube of diluted semen was cooled to $4{ }^{\circ} \mathrm{C}$ for $75 \mathrm{~min}$ and then evaluated using ISAS. Straws $(0.5 \mathrm{~mL})$ were filled with diluted semen. Freezing was performed with a programmable freezer (nitrogen freezer, automatic Mini-Digitcool, IMV-Technologies, L'Aigle, France) $\left(-60^{\circ} \mathrm{C} / \mathrm{min}\right.$. up to $\left.-140^{\circ} \mathrm{C}\right)$. The straws were kept in liquid nitrogen for seven days and then thawed in a water bath $\left(37^{\circ} \mathrm{C}\right)$ for $30 \mathrm{~s}$ immediately before they were analyzed by ISAS system. 
Gum arabic effect on stallion sperm during cold storage and post freezing

Assessment of sperm motility

Immediately after gentle mixing, $1.0 \mathrm{~mL}$ of semen was taken from each bottle and examined for motility pattern using the CASA system (ISAS ${ }^{\circledR}$ program, Proiser R+D, Paterna, Valencia, Spain). A sample $(2.7 \mu \mathrm{L})$ was placed in a pre-warmed counting chamber (Leja ${ }^{\circledR}$, Luzernestraat, The Netherlands). Sperm motility analysis was conducted based on the examination of five consecutive digitalized images obtained from several fields using a X10 negativephase contrast objective and a warm stage at $38^{\circ} \mathrm{C}$. Values for kinetic parameters were acquired by assessing 300-400 cells for each sample. Images were taken with a time lapse of one second. The following sperm motility parameters were recorded: total motile spermatozoa (\% TMS), the curvilinear velocity (VCL $\mu \mathrm{m} / \mathrm{s}$ ), the straight line velocity (VSL $\mu \mathrm{m} / \mathrm{s}$ ), the average path velocity (VAP $\mu \mathrm{m} / \mathrm{s}$ ), the linearity (LIN \%) and straightness index (STR $>0.8,80 \%$ ). Spermatozoa with VAP values $<10 \mu \mathrm{m} / \mathrm{s}$ were considered immotile. However, spermatozoa with a velocity VAP $>20 \mu \mathrm{m} / \mathrm{s}$, VSL $>30 \mu \mathrm{m} / \mathrm{s}$ and VCL $>45 \mu \mathrm{m} / \mathrm{s}$ were considered motile. The parameters of sperm motility included the percentage of rapid (RMS), medium (MMS) and slow (SMS) progressively motile spermatozoa, which were calculated by counting spermatozoa with a swimming speed of $>90,45-$ 90 and $10-45 \mu \mathrm{m} / \mathrm{s}$, respectively being expressed as percentage of all analyzed spermatozoa. Those with a swimming speed below $10 \mu \mathrm{m} / \mathrm{s}$ were considered immotile spermatozoa (IMS).

\section{Evaluation of frozen semen}

Frozen semen was thawed and then evaluated for vitality, morphological defects, acrosome and plasma membrane integrities.

\section{Hypo-osmotic swelling test (HOST)}

The integrity of the plasma membrane was evaluated by hypo-osmotic swelling test (HOST) in frozen-thawed semen. A solution of $100 \mathrm{mOsmol}$ sucrose-base was used. Aliquots of $1.0 \mathrm{~mL}$ of this solution were placed in tubes at $37{ }^{\circ} \mathrm{C}$ and $20 \mu \mathrm{L}$ of fresh semen sample was added to each tube and incubated for 50 minutes in a water bath at $37{ }^{\circ} \mathrm{C}$. Subsequently, the spermatozoa were analyzed by counting 100 sperm cells from each sample in phase contrast microscopy $(400 \times)$. The cells were classified by the presence or absence of coiled tail (11).

\section{Acrosome integrity}

Defected acrosomes were evaluated using the Giemsa staining procedure (12). Two hundred spermatozoa were examined by a light microscope
$(1,000 \times)$ to determine the percentages of spermatozoa with defected acrosome.

\section{Normal morphology}

The nigrosin-eosin stain was used to examine the morphology of spermatozoa (13). Two hundred spermatozoa were examined by a light microscope $(1,000 \times)$ to determine the percentage of spermatozoa with morphological defects.

\section{Vital test}

A combination of two fluorescent stains, acridine orange (AO) and propidium iodide (PI) (Halotech DNA, S.L. Spain) were used to assess cell viability. We checked the ability of AO and PI molecules to cross cell membranes; $\mathrm{AO}$ was retained within intact cells, causing them to fluoresce green, however PI cannot penetrate living cells, but can only bind to and stain cellular DNA in damaged cells, giving them red fluorescence. Each sperm sample was diluted to a final concentration of $10-15 \times 10^{6} / \mathrm{mL}$. On a clean slide, $1 \mu \mathrm{L}$ of $\mathrm{AO}$ and $1 \mu \mathrm{L}$ of PI were mixed with $10 \mu \mathrm{L}$ of diluted sperm sample and then covered with a clean coverslip. Stained specimens were then observed under the fluorescence microscope, and a minimum of 300 sperm per sample were counted.

\section{Statistical analysis}

Data were analyzed using a statistical software SPSS release 16.0. Statistical comparisons between groups were performed with a one-way analysis of variance (ANOVA) $(\mathrm{P}<0.05)$. Analysis of the normal distribution of data was examined with Kolmogorov-Smirnov test (14). Kruskal-Wallis one way ANOVA test were used for the data which were not normally distributed and the variance of the observations in groups was not the same (14).

\section{RESULTS}

Effect of various extenders and cold temperature on stallion' sperm motility

The effect of low temperature $\left(4^{\circ} \mathrm{C}\right)$ on $\mathrm{pH}$, viscosity and osmolarity of refrigerated HF-20 diluents [GA (3, 9, and 15\%) and EY (10 and 20\%)] is demonstrated in Table 1. Cooling the samples to $4{ }^{\circ} \mathrm{C}$ showed no effects on the values of osmolarity and $\mathrm{pH}$ compared with values obtained at 4 and $36{ }^{\circ} \mathrm{C}$. However, a consistent increase in viscosity was noticed upon decreasing the temperature to 4 ${ }^{\circ} \mathrm{C}$ with all the extenders. Cooling samples to $4{ }^{\circ} \mathrm{C}$ resulted in a two-folds increase in viscosity when compared to that at $36^{\circ} \mathrm{C}$ in all extenders. 
Table 1. Viscosity, $\mathrm{pH}$, and osmolarity of cold HF-20 diluents at $4{ }^{\circ} \mathrm{C}$ and $36^{\circ} \mathrm{C}$

\begin{tabular}{ccccc}
\hline Extender (HF-20) & $\begin{array}{c}\text { Storage temperature } \\
\left({ }^{\circ} \mathbf{C}\right)\end{array}$ & pH & $\begin{array}{c}\text { Viscosity } \\
(\mathbf{c P}) *\end{array}$ & $\begin{array}{c}\mathbf{O s m o l a r i t y}^{*} \\
(\mathbf{m O s m o l} / \mathbf{k g H} \mathbf{O})\end{array}$ \\
\hline \multirow{2}{*}{ Distilled water } & 36 & 5.7 & 3.1 & -7 \\
\hline \multirow{2}{*}{ GA (3\%) } & 4 & 5.5 & 4.2 & -7 \\
\hline \multirow{2}{*}{ GA (9\%) } & 36 & 7.1 & 2.6 & 308 \\
\hline \multirow{2}{*}{ GA (15\%) } & 4 & 7.1 & 4.0 & 397 \\
\hline \multirow{2}{*}{ EY (10\%) } & 36 & 6.6 & 5.3 & 393 \\
\hline \multirow{2}{*}{ EY (20\%) } & 36 & 6.7 & 9.8 & 478 \\
& 4 & 6.8 & 15.3 & 477 \\
\hline
\end{tabular}

$*_{\mathrm{c}} \mathrm{P}=$ Centipose; a measure of viscosity

The effect of various concentrations of GA and EY on various motility parameters of sperm at $4{ }^{\circ} \mathrm{C}$ involving rapid motile sperm (RMS), medium motile sperm (MMS), and immotile sperm (IMS) is demonstrated in Table 2. Increasing the percentage of GA or EY in extenders resulted in a linear increase in viscosity. The RMS was similar in EY
$(10 \%)$ and GA ( 3 and $9 \%)$ upon adding the extender to semen (i.e., at zero time). Cooling the extenders for 24 hours resulted in higher values of RMS in EY $(10 \%)$ and GA $(3 \%)$ when compared to other extenders. A similar trend was observed at longer cooling periods (48 and 72 hours).

Table 2. Motility parameters of stallion semen diluted with extenders containing GA or EY and stored at $4{ }^{\circ} \mathrm{C}$ for various times (mean $\pm \mathrm{SEM}$ )

\begin{tabular}{llllccc}
\hline \multirow{2}{*}{$\begin{array}{c}\text { Motility } \\
\text { Parameter }\end{array}$} & $\begin{array}{l}\text { Storage } \\
\text { time (h) }\end{array}$ & \multicolumn{5}{c}{ Extenders with Gum Arabic (GA) or Egg Yolk (EY) } \\
\cline { 3 - 7 } & 0 & $80.28 \pm 16.8^{\mathrm{a}}$ & $60.37 \pm 6.09^{\mathrm{ab}}$ & $73.25 \pm 16.55^{\mathrm{a}}$ & $75.56 \pm 12.61^{\mathrm{a}}$ & $35.43 \pm 5.08^{\mathrm{b}}$ \\
& 4 & $59.60 \pm 4.00^{\mathrm{a}}$ & $44.70 \pm 1.30^{\mathrm{a}}$ & $59.20 \pm 5.20^{\mathrm{a}}$ & $60.10 \pm 2.60^{\mathrm{a}}$ & $32.25 \pm 8.50^{\mathrm{b}}$ \\
& 24 & $55.00 \pm 10.20^{\mathrm{a}}$ & $28.15 \pm 7.75^{\mathrm{ab}}$ & $47.46 \pm 10.3^{\mathrm{a}}$ & $27.63 \pm 4.21^{\mathrm{ab}}$ & $20.90 \pm 0.40^{\mathrm{b}}$ \\
& 48 & $47.05 \pm 22.3^{\mathrm{a}}$ & $17.70 \pm 0.70^{\mathrm{ab}}$ & $33.25 \pm 5.25^{\mathrm{a}}$ & $6.10 \pm 1.90^{\mathrm{b}}$ & $7.90 \pm 0.40^{\mathrm{b}}$ \\
& 72 & $8.15 \pm 1.85^{\mathrm{a}}$ & $2.65 \pm 0.65^{\mathrm{b}}$ & $6.86 \pm 3.27^{\mathrm{a}}$ & $0.00 \pm 0.00$ & $0.00 \pm 0.00$ \\
& 96 & $7.50 \pm 2.50^{\mathrm{a}}$ & $1.50 \pm 0.50^{\mathrm{b}}$ & $2.10 \pm 0.70^{\mathrm{b}}$ & $0.00 \pm 0.00$ & $0.00 \pm 0.00$ \\
\hline & 0 & $13.40 \pm 10.9^{\mathrm{b}}$ & $21.50 \pm 3.36^{\mathrm{ab}}$ & $13.60 \pm 7.30^{\mathrm{b}}$ & $15.20 \pm 6.00^{\mathrm{b}}$ & $27.00 \pm 4.7^{\mathrm{a}}$ \\
& 4 & $15.20 \pm 2.60^{\mathrm{b}}$ & $24.22 \pm 1.80^{\mathrm{ab}}$ & $21.85 \pm 0.25^{\mathrm{ab}}$ & $21.60 \pm 1.20^{\mathrm{ab}}$ & $27.66 \pm 1.20^{\mathrm{a}}$ \\
& 24 & $19.85 \pm 7.35$ & $24.35 \pm 1.25$ & $19.00 \pm 1.53$ & $17.40 \pm 2.63$ & $20.90 \pm 0.48$ \\
& 48 & $19.50 \pm 5.40^{\mathrm{ab}}$ & $28.05 \pm 0.95^{\mathrm{a}}$ & $26.05 \pm 3.60^{\mathrm{a}}$ & $12.00 \pm 3.06^{\mathrm{b}}$ & $14.00 \pm 1.40^{\mathrm{b}}$ \\
& 72 & $16.10 \pm 1.10^{\mathrm{a}}$ & $11.60 \pm 0.60^{\mathrm{b}}$ & $9.46 \pm 0.80^{\mathrm{b}}$ & $0.00 \pm 0.00$ & $0.00 \pm 0.00$ \\
& 96 & $17.85 \pm 6.80^{\mathrm{a}}$ & $10.50 \pm 0.50^{\mathrm{ab}}$ & $5.90 \pm 1.40^{\mathrm{b}}$ & $0.00 \pm 0.00$ & $0.00 \pm 0.00$ \\
\hline & 0 & $3.50 \pm 3.20^{\mathrm{b}}$ & $23.45 \pm 6.50^{\mathrm{ab}}$ & $5.45 \pm 0.85^{\mathrm{b}}$ & $4.63 \pm 3.00^{\mathrm{b}}$ & $27.83 \pm 9.66^{\mathrm{a}}$ \\
& 4 & $24.15 \pm 1.20^{\mathrm{a}}$ & $28.45 \pm 2.40^{\mathrm{a}}$ & $10.55 \pm 3.80^{\mathrm{b}}$ & $10.45 \pm 0.00^{\mathrm{b}}$ & $25.25 \pm 5.60^{\mathrm{a}}$ \\
& 24 & $22.80 \pm 1.00$ & $42.25 \pm 7.85$ & $27.56 \pm 10.10$ & $49.03 \pm 7.61$ & $53.95 \pm 12.55$ \\
& 48 & $24.65 \pm 8.50^{\mathrm{b}}$ & $30.30 \pm 0.40^{\mathrm{b}}$ & $27.15 \pm 1.35^{\mathrm{b}}$ & $70.85 \pm 10.35^{\mathrm{a}}$ & $56.70 \pm 0.00^{\mathrm{a}}$ \\
& 72 & $35.05 \pm 5.05^{\mathrm{b}}$ & $53.50 \pm 6.50^{\mathrm{b}}$ & $63.66 \pm 7.29^{\mathrm{b}}$ & $100 \pm 0.00^{\mathrm{a}}$ & $100 \pm 0.00^{\mathrm{a}}$ \\
& 96 & $60.45 \pm 19.55^{\mathrm{b}}$ & $60.00 \pm 0.00^{\mathrm{b}}$ & $74.85 \pm 6.45^{\mathrm{b}}$ & $100 \pm 0.00^{\mathrm{a}}$ & $100 \pm 0.00^{\mathrm{a}}$ \\
\hline
\end{tabular}

a,b,c Values with different superscripts in the same row within a category differ significantly at $\mathrm{P}<0.05$, ANOVA 
The results for MMS showed a noticeable influence on motility at relatively high concentrations of GA $(15 \%)$ at short storage time (0-4 hours). However, storage for 24 hours resulted in similar MMS values for all extenders. Storage for 48 hours resulted in higher MMS values for EY $(20 \%)$ and GA $(3 \%)$ when compared to other extenders. Egg yolk at 10\% gave the best MMS rates for extenders that were stored for longer periods ( $>72$ hours).

IMS values were significantly low in GA ( $3 \%$ and $9 \%$ ) at short storage time ( 0 to 4 hours) compared with GA (15\%) and EY (20\%). However, an increase in the IMS was observed at prolonged storage periods ( $>48$ hours) with all extenders. At storage time of 48,72 or 96 hours, the IMS values were significantly higher $(\mathrm{P}<0.05)$ in GA $(9 \%)$ and GA (15\%) compared to other extenders.

Data of the effect of various concentrations of $\mathrm{EY}$ and GA on the motion kinetics of the stallion sperm, including the average velocity parameters: curvilinear velocity (VCL), straight line velocity (VSL) and average path velocity (VAP), as well as the percent progression [i.e. linearity coefficient

Table 3. Effect of level of EY or GA in stallion' semen extender on sperm speed stored at $4^{\circ} \mathrm{C}(\mathrm{mean} \pm \mathrm{SEM})$

\begin{tabular}{|c|c|c|c|c|c|c|}
\hline \multirow{2}{*}{$\begin{array}{c}\text { Speed } \\
\text { parameter }\end{array}$} & \multirow{2}{*}{$\begin{array}{l}\text { Storage } \\
\text { time (h) }\end{array}$} & \multicolumn{5}{|c|}{ Extenders with Gum Arabic (GA) or Egg Yolk (EY) } \\
\hline & & EY $(10 \%)$ & EY $(20 \%)$ & GA $(3 \%)$ & GA $(9 \%)$ & GA $(15 \%)$ \\
\hline \multirow{6}{*}{$\operatorname{VCL}(\mu \mathrm{m} / \mathrm{s})$} & 0 & $116.10 \pm 21.2^{\mathrm{a}}$ & $74.10 \pm 4.90^{\mathrm{b}}$ & $97.45 \pm 22.35^{\mathrm{a}}$ & $106.8 \pm 11.0^{\mathrm{a}}$ & $67.16 \pm 1.79^{b}$ \\
\hline & 4 & $80.65 \pm 7.60^{\mathrm{a}}$ & $65.67 \pm 1.90^{\mathrm{b}}$ & $93.45 \pm 4.40^{\mathrm{a}}$ & $90.85 \pm 2.50^{\mathrm{a}}$ & $74.60 \pm 6.50^{\mathrm{b}}$ \\
\hline & 24 & $72.30 \pm 9.90$ & $54.90 \pm 5.10$ & $74.03 \pm 11.80$ & $66.13 \pm 6.89$ & $59.45 \pm 4.45$ \\
\hline & 48 & $74.25 \pm 8.15$ & $59.30 \pm 2.30$ & $57.40 \pm 22.7$ & $47.70 \pm 8.30$ & $51.85 \pm 1.45$ \\
\hline & 72 & $42.72 \pm 2.75^{\mathrm{ab}}$ & $39.70 \pm 0.30^{\mathrm{b}}$ & $50.76 \pm 4.27^{\mathrm{a}}$ & $0.00 \pm 0.00$ & $0.00 \pm 0.00$ \\
\hline & 96 & $46.20 \pm 12.20$ & $37.00 \pm 4.70$ & $37.80 \pm 3.60$ & $0.00 \pm 0.00$ & $0.00 \pm 0.00$ \\
\hline \multirow{6}{*}{$\operatorname{VSL}(\mu \mathrm{m} / \mathrm{s})$} & 0 & $26.05 \pm 4.85^{\mathrm{a}}$ & $18.15 \pm 1.09^{b}$ & $32.05 \pm 6.15^{\mathrm{a}}$ & $25.7 \pm 2.15^{\mathrm{a}}$ & $16.90 \pm 1.32^{b}$ \\
\hline & 4 & $19.00 \pm 0.60^{\mathrm{ab}}$ & $17.22 \pm 0.10^{\mathrm{b}}$ & $22.30 \pm 1.40^{\mathrm{a}}$ & $19.40 \pm 1.0^{\mathrm{ab}}$ & $17.00 \pm 0.60^{\mathrm{b}}$ \\
\hline & 24 & $17.90 \pm 0.70^{\mathrm{a}}$ & $15.40 \pm 1.50^{\mathrm{ab}}$ & $17.03 \pm 11.80^{\mathrm{a}}$ & $13.80 \pm 0.25^{\mathrm{b}}$ & $13.40 \pm 0.70^{\mathrm{b}}$ \\
\hline & 48 & $18.75 \pm 1.45^{\mathrm{a}}$ & $17.15 \pm 0.15^{\mathrm{a}}$ & $15.20 \pm 0.1^{0 \mathrm{a} b}$ & $12.25 \pm 1.45^{b}$ & $12.75 \pm 0.75^{b}$ \\
\hline & 72 & $12.50 \pm 1.50$ & $13.05 \pm 0.05$ & $11.36 \pm 0.44$ & $0.00 \pm 0.00$ & $0.00 \pm 0.00$ \\
\hline & 96 & $13.80 \pm 2.80$ & $14.60 \pm 1.60$ & $9.55 \pm 1.45$ & $0.00 \pm 0.00$ & $0.00 \pm 0.00$ \\
\hline \multirow{6}{*}{$\operatorname{VAP}(\mu \mathrm{m} / \mathbf{s})$} & 0 & $56.25 \pm 10.0^{\mathrm{a}}$ & $37.65 \pm 2.60^{\mathrm{b}}$ & $56.40 \pm 14.30^{\mathrm{a}}$ & $52.10 \pm 5.10^{\mathrm{a}}$ & $36.00 \pm 2.80^{\mathrm{b}}$ \\
\hline & 4 & $40.35 \pm 2.20^{\mathrm{a}}$ & $35.45 \pm 0.58^{b}$ & $43.55 \pm 2.70^{\mathrm{a}}$ & $41.30 \pm 0.20^{\mathrm{a}}$ & $37.05 \pm 2.40^{\mathrm{b}}$ \\
\hline & 24 & $36.80 \pm 2.80$ & $30.15 \pm 2.8$ & $35.03 \pm 4.29$ & $30.80 \pm 1.98$ & $28.75 \pm 2.35$ \\
\hline & 48 & $38.55 \pm 3.94$ & $34.20 \pm 0.20$ & $29.25 \pm 7.15$ & $24.15 \pm 3.45$ & $26.40 \pm 0.20$ \\
\hline & 72 & $25.65 \pm 0.65$ & $24.05 \pm 0.05$ & $24.16 \pm 1.27$ & $0.00 \pm 0.00$ & $0.00 \pm 0.00$ \\
\hline & 96 & $26.60 \pm 5.60$ & $27.65 \pm 3.65$ & $19.40 \pm 2.20$ & $0.00 \pm 0.00$ & $0.00 \pm 0.00$ \\
\hline \multirow{6}{*}{ LIN (\%) } & 0 & $22.40 \pm 0.10^{\mathrm{b}}$ & $24.52 \pm 0.30^{\mathrm{b}}$ & $33.15 \pm 1.25^{\mathrm{a}}$ & $24.20 \pm 0.60^{\mathrm{b}}$ & $23.66 \pm 0.70^{b}$ \\
\hline & 4 & $23.65 \pm 1.45^{\mathrm{ab}}$ & $26.30 \pm 0.85^{\mathrm{a}}$ & $23.90 \pm 0.40^{\mathrm{ab}}$ & $21.40 \pm 1.70^{\mathrm{b}}$ & $22.95 \pm 1.15^{\mathrm{ab}}$ \\
\hline & 24 & $25.10 \pm 2.50^{\mathrm{ab}}$ & $27.95 \pm 0.15^{\mathrm{a}}$ & $23.66 \pm 2.00^{\mathrm{ab}}$ & $21.30 \pm 1.77^{\mathrm{b}}$ & $22.55 \pm 0.45^{\mathrm{ab}}$ \\
\hline & 48 & $25.35 \pm 0.85$ & $27.50 \pm 0.50$ & $31.30 \pm 12.20$ & $26.00 \pm 1.50$ & $24.55 \pm 2.15$ \\
\hline & 72 & $28.80 \pm 1.80^{\mathrm{a}}$ & $31.70 \pm 1.70^{\mathrm{a}}$ & $22.56 \pm 1.00^{\mathrm{b}}$ & $0.00 \pm 0.00$ & $0.00 \pm 0.00$ \\
\hline & 96 & $26.20 \pm 2.20^{\mathrm{ab}}$ & $30.00 \pm 0.01^{\mathrm{a}}$ & $25.05 \pm 1.45^{\mathrm{b}}$ & $0.00 \pm 0.00$ & $0.00 \pm 0.00$ \\
\hline \multirow{6}{*}{ STR (\%) } & 0 & $46.20 \pm 0.40^{b}$ & $48.30 \pm 1.00^{\mathrm{b}}$ & $57.80 \pm 3.70^{\mathrm{a}}$ & $49.50 \pm 0.86^{b}$ & $47.00 \pm 0.40^{b}$ \\
\hline & 4 & $47.25 \pm 1.10^{\mathrm{ab}}$ & $48.60 \pm 0.84^{\mathrm{ab}}$ & $51.30 \pm 0.00^{\mathrm{a}}$ & $47.00 \pm 2.20^{\mathrm{b}}$ & $46.00 \pm 1.40^{\mathrm{b}}$ \\
\hline & 24 & $48.75 \pm 1.85$ & $50.95 \pm 0.001$ & $49.26 \pm 2.71$ & $45.20 \pm 2.15$ & $46.70 \pm 1.20$ \\
\hline & 48 & $48.80 \pm 1.30$ & $50.10 \pm 0.10$ & $55.20 \pm 13.20$ & $50.95 \pm 1.25$ & $48.10 \pm 2.50$ \\
\hline & 72 & $51.05 \pm 2.05^{\mathrm{ab}}$ & $52.20 \pm 2.20^{\mathrm{a}}$ & $47.10 \pm 0.75^{\mathrm{b}}$ & $0.00 \pm 0.00$ & $0.00 \pm 0.00$ \\
\hline & 96 & $50.75 \pm 0.75$ & $50.85 \pm 0.85$ & $48.90 \pm 2.00$ & $0.00 \pm 0.00$ & $0.00 \pm 0.00$ \\
\hline
\end{tabular}

a,b,c: Values with different superscripts in the same row within a parameter differ significantly at $\mathrm{P}<0.05$, ANOVA. 


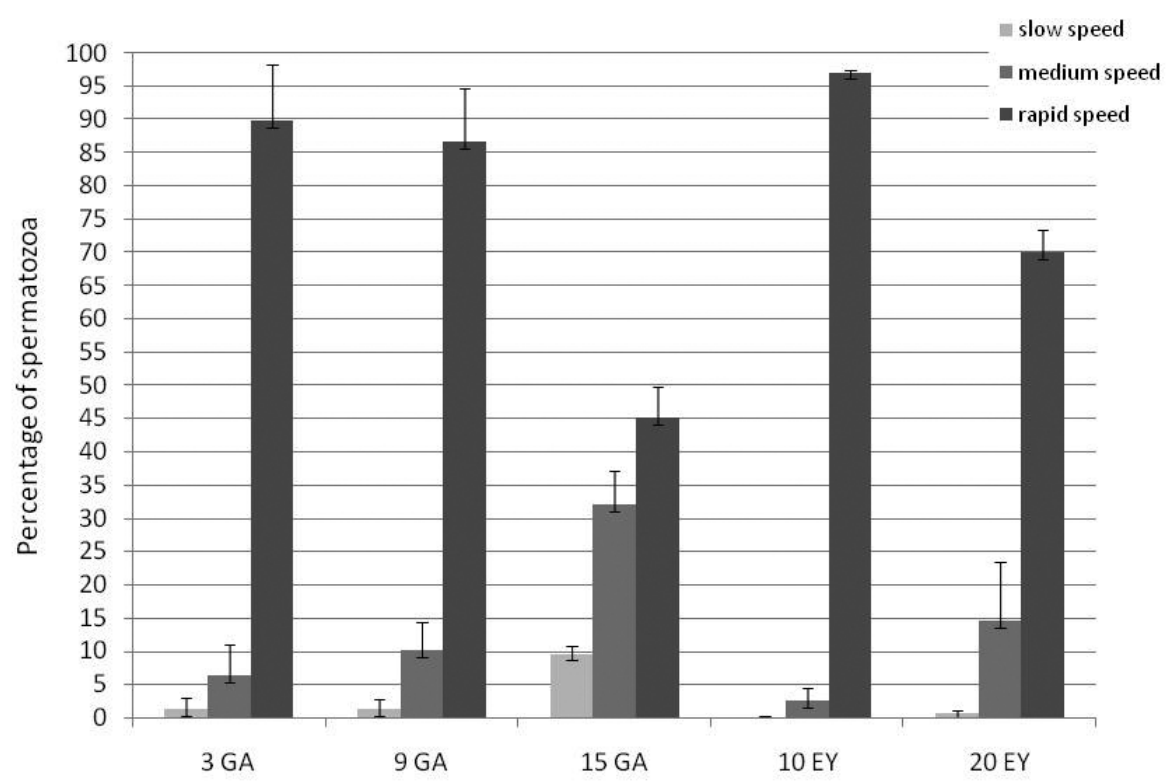

Extenders with different concentration of Gum Arabic (GA) or egg yolk (EY)

Figure 1. Distribution of sperm velocity in fresh semen diluted with HF-20 extender containing different concentrations of GA (3, 9 and 15\%) or EY (10\% and 20\%). Based on 5000 sperm for each diluent

(LIN) and straightness index (STR)] of stallion sperm, at various cold storage periods are shown in Table 3. The overall results revealed that increasing the concentration of EY or GA in the extender significantly decreased sperm speed in cooled semen.
The VCL values were significantly higher $(\mathrm{P}<0.05)$ in $\mathrm{EY}(10 \%)$ and GA (3\% and 9\%) compared to $\mathrm{EY}$ $(20 \%)$ and GA $(15 \%)$ at early stage of cooling (i.e. 0 to $4 \mathrm{~h})$. However, similar VCL values were observed for all extenders at longer storage times (24 and $48 \mathrm{~h}$ ).

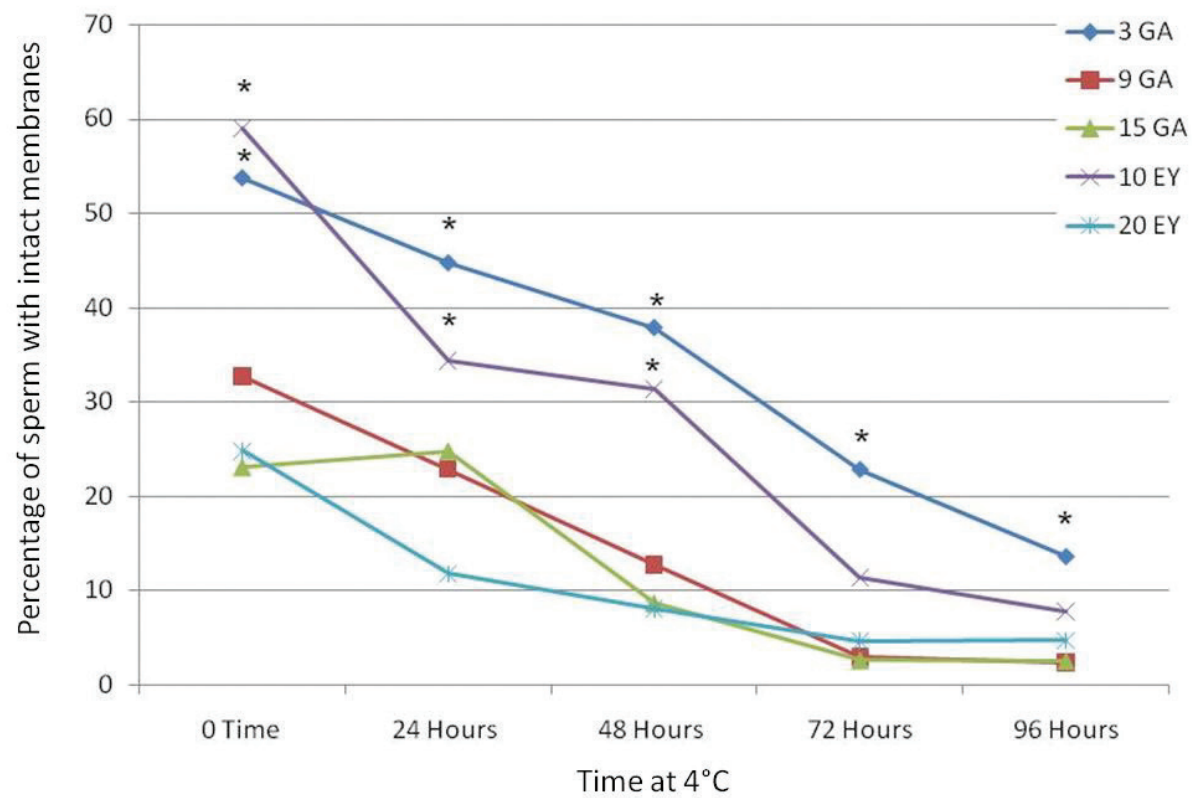

Figure 2. Percentage of intact cell with bent, curved and broken midpiece or tail at various cold storage times. *Significant difference among groups 
Table 4. Effect of gum Arabic (GA) and egg yolk (EY) on stallion sperm acrosome integrity, plasma membrane integrity and morphology after 24 hours of cooling

\begin{tabular}{lccccc}
\hline \multicolumn{1}{c}{ Parameter } & EY (10\%) & EY (20\%) & GA (3\%) & GA (9\%) & GA (15\%) \\
HOST (\%) & $34.39 \pm 1.4^{\mathrm{a}}$ & $11.72 \pm 0.9^{\mathrm{b}}$ & $44.78 \pm 3.4^{\mathrm{a}}$ & $22.87 \pm 1.4^{\mathrm{b}}$ & $24.70 \pm 8.0^{\mathrm{b}}$ \\
Acrosome integrity (\%) & $81.46 \pm 1.9^{\mathrm{a}}$ & $73.00 \pm 2.0^{\mathrm{a}}$ & $81.15 \pm 4.9^{\mathrm{a}}$ & $80.85 \pm 0.1^{\mathrm{a}}$ & $81.00 \pm 2.0^{\mathrm{a}}$ \\
Normal sperm morphology (\%) & $89.99 \pm 6.5^{\mathrm{a}}$ & $73.18 \pm 3.7^{\mathrm{a}}$ & $84.39 \pm 2.9^{\mathrm{a}}$ & $83.65 \pm 7.6^{\mathrm{a}}$ & $77.26 \pm 3.9^{\mathrm{a}}$ \\
\hline
\end{tabular}

${ }^{\mathrm{a}, \mathrm{b}}$ Values with different superscripts in the same row differ significantly at $\mathrm{P}<0.05$; ANOVA

After $\geq 72 \mathrm{~h}$ of cooling, the VCL values were similar for EY (10\% and 20\%) and GA (3\%). Excluding the initial reduction that was observed upon cooling the diluted stallion semen using EY (20\%), VSL values for the stallion sperm were similar when EY $(10 \%$ and $20 \%$ ) or GA (3\%) were used. A significant decrease in VSL of sperm was observed upon increasing the storage time in all extenders. Similar behavior was observed for VAP. VAP values in high viscosity extenders [EY (20\%) and GA (15\%)] were lower than those with lower viscosity during short preservation periods ( 0 to $4 \mathrm{~h}$ ). However, in all extenders, the VAP values were similar at longer storage time.

LIN and STR were comparable in EY $(10 \%$ and $20 \%$ ) and GA (3\%). Extending the storage time for extenders containing EY (10\%) and EY (20\%) resulted in slight increases in the LIN and STR values.

The distribution of sperm velocity in each diluent on fresh semen is shown in Fig 1. The highest values of slow and medium motile sperm (SMS and MMS) were recorded when extenders containing $15 \%$ GA were used, while RMS in $10 \%$ EY was higher than that of other extenders. Note that the sperm motility decreased upon increasing viscosity of diluents. However, the motility of sperm decreased with increasing time of storage (Table 2).

The integrity of the plasma membrane by HOST test was evaluated at various stages of cooling

Table 5. Motility and kinetic parameters in frozen-thawed semen stored in liquid nitrogen for seven days ${ }^{\mathrm{a}}$

\begin{tabular}{lllll}
\hline Parameter & EY (10\%) & GA (3\%) & GA (9\%) & GA (15\%) \\
\hline RMS (\%) & $26.12 \pm 7.95^{\mathrm{b}}$ & $38.26 \pm 2.26^{\mathrm{a}}$ & $16.62 \pm 6.18^{\mathrm{b}}$ & $3.76 \pm 1.16^{\mathrm{bc}}$ \\
MMS (\%) & $28.00 \pm 2.62^{\mathrm{a}}$ & $22.00 \pm 3.00^{\mathrm{a}}$ & $17.95 \pm 2.84^{\mathrm{b}}$ & $7.65 \pm 0.38^{\mathrm{bc}}$ \\
TMS (\%) & $51.57 \pm 8.25^{\mathrm{a}}$ & $60.26 \pm 0.73^{\mathrm{a}}$ & $34.17 \pm 8.62^{\mathrm{b}}$ & $11.40 \pm 1.51^{\mathrm{bc}}$ \\
IMS (\%) & $28.02 \pm 8.84^{\mathrm{b}}$ & $33.80 \pm 0.50^{\mathrm{b}}$ & $49.40 \pm 5.59^{\mathrm{b}}$ & $72.93 \pm 0.94^{\mathrm{a}}$ \\
VCL $(\boldsymbol{\mu m} / \mathbf{s})$ & $62.47 \pm 5.20^{\mathrm{a}}$ & $64.90 \pm 4.40^{\mathrm{a}}$ & $57.75 \pm 3.21^{\mathrm{a}}$ & $47.30 \pm 2.81^{\mathrm{b}}$ \\
VSL $(\boldsymbol{\mu m} / \mathbf{s})$ & $17.82 \pm 1.67^{\mathrm{a}}$ & $15.36 \pm 0.13^{\mathrm{a}}$ & $15.05 \pm 0.85^{\mathrm{a}}$ & $11.40 \pm 0.61^{\mathrm{b}}$ \\
VAP( $\boldsymbol{\mu m} / \mathbf{s})$ & $34.52 \pm 3.22^{\mathrm{a}}$ & $32.26 \pm 0.56^{\mathrm{a}}$ & $30.05 \pm 1.65^{\mathrm{a}}$ & $23.50 \pm 1.35^{\mathrm{b}}$ \\
LIN $(\%)$ & $28.57 \pm 1.07^{\mathrm{a}}$ & $23.90 \pm 1.70^{\mathrm{b}}$ & $26.05 \pm 0.55^{\mathrm{ab}}$ & $24.13 \pm 0.61^{\mathrm{b}}$ \\
STR $(\%)$ & $51.70 \pm 0.67^{\mathrm{a}}$ & $50.00 \pm 1.20^{\mathrm{a}}$ & $50.07 \pm 0.25^{\mathrm{a}}$ & $48.60 \pm 0.51^{\mathrm{b}}$ \\
\hline
\end{tabular}

${ }^{a}$ Based on the ejaculates of three stallions

a,b,c Values with different superscripts in the same row differ significantly at $\mathrm{P}<0.05$, ANOVA

RMS: rapid motile sperm, MMS: medium motile sperm, IMS: immotile sperm, TMS: total motile spermatozoa, VCL: the curvilinear velocity, VSL: the straight line velocity, VAP: the average path velocity, LIN: the linearity and STR: straightness index

Table 6. Effect of gum Arabic (GA) and egg yolk (EY) on acrosome integrity, plasma membrane integrity and morphology of frozen-thawed stallion semen

\begin{tabular}{lllll}
\hline Parameters & EY (10\%) & GA (3\%) & GA (9\%) & GA (15\%) \\
HOST (\%) & $21.53 \pm 0.01^{\mathrm{b}}$ & $34.25 \pm 9.38^{\mathrm{a}}$ & $18.50 \pm 7.21^{\mathrm{b}}$ & $12.00 \pm 9.60^{\mathrm{b}}$ \\
Vital test (\%) & $32.43 \pm 4.18^{\mathrm{a}}$ & $41.05 \pm 8.60^{\mathrm{a}}$ & $22.61 \pm 0.01^{\mathrm{b}}$ & $2.50 \pm 1.00^{\mathrm{b}}$ \\
Acrosome integrity (\%) & $73.88 \pm 0.59^{\mathrm{a}}$ & $78.57 \pm 2.29^{\mathrm{a}}$ & $81.57 \pm 1.99^{\mathrm{a}}$ & $80.00 \pm 0.92^{\mathrm{a}}$ \\
Normal sperm morphology (\%) & $81.50 \pm 5.70^{\mathrm{a}}$ & $79.58 \pm 3.38^{\mathrm{a}}$ & $70.72 \pm 5.08^{\mathrm{a}}$ & $76.15 \pm 0.35^{\mathrm{a}}$ \\
\hline
\end{tabular}

${ }^{\mathrm{a}, \mathrm{b}}$ Values with different superscripts in the same row differ significantly at $\mathrm{P}<0.05$, ANOVA 
(Fig 2). The mean percentage of HOST coiling of stallion sperm tail was significantly higher in GA $(3 \%)$ and EY (10\%) than those of other extenders. Moreover, mean percentage of HOST coiling tail was significantly higher $(\mathrm{P}<0.05)$ in GA $(3 \%)$ at all times of cold storage than that of other extenders.

As shown in Table 4, there were non-significant $(\mathrm{P}>0.05)$ differences due to GA or EY levels on the sperm integrity.

\section{Effect of deep-freezing on sperm motility}

Values of motility and speed parameters of stallion sperm after deep freezing in liquid nitrogen are shown in Table 5. The extenders containing GA $(3 \%)$ showed a significantly $(\mathrm{P}<0.05)$ higher RMS compared to other extenders. MMS and TMS values were similar in EY (10\%) and GA (3\%), but significantly lower $(\mathrm{p}<0.05)$ in GA $(9 \%$ and $15 \%)$. The IMS value was significantly higher $(\mathrm{P}<0.05)$ in the extender containing GA (15\%). Influence of high viscosity on sperm speed was obvious in the extender containing GA (15\%) after deep-freezing. Therefore, other extenders had significantly higher $(\mathrm{P}<0.05)$ speed parameters of sperm compared to the extender containing GA (15\%).

A significantly higher plasma membrane integrity (HOST) was obtained with extender containing 3\% GA, compared to GA (9 and 15\%) and EY (10\%). The vital tests were significantly higher in GA $(3 \%)$ and EY (10\%). However, the vitality of sperm decreased with increasing concentration of GA. Percentage of acrosome integrity and sperm defects were not different between GA and EY (Table 6).

\section{DISCUSSION}

To our knowledge, this is the first study to use GA as a substitute for EY in stallion semen extenders. In the present study, we describe the effect of changing the concentration of GA on the viscosity of extenders and motility of spermatozoa evaluated by ISAS. Due to the nature of generating data for sub-populations of spermatozoa in a given sample, any factor that changes the pattern of sperm motion can affect parameters like percentage of progressively motile spermatozoa. It is well known that the viscosity in the medium surrounding the spermatozoa affects the pattern of sperm motion (15).

In previous studies $(5,16,17)$, different levels of viscosity were achieved by the addition of Ficoll, carboxymethyl cellulose, methylcellulose or EY. The results of the present study demonstrates that addition of GA could also alter the movement pattern of spermatozoa. The decrease in the average velocity (VCL, VSL, and VAP) corresponds well to the results of Suarez and Dai (18), who used ficoll as semen extender in their experiments. Obviously, the elevated viscosity primarily affected fast swimming sperm cells and spermatozoa with a velocity slightly above $45 \mu \mathrm{m} / \mathrm{s}$, the latter to a minor extent. This hypothesis is supported by the fact that the percentage of IMS $(<10 \mu \mathrm{m} / \mathrm{s})$ raised significantly after adding $15 \%$ of GA to the extender.

Data of IMS demonstrated that the increase in the level of EY in the extender resulted in higher particles or debris that could affect the accuracy of computer-detected spermatozoa and thus expressing these particles as false spermatozoa. It has been recommended that the particulate fraction could be reduced from EY extender by sedimentation, decantation or filtration for better results of the computer-assisted system (5).

A clear increase in viscosity as a function of GA concentration was observed. The viscosity of GA extenders increased after cooling to $4{ }^{\circ} \mathrm{C}$ or after rapid freezing to $-196{ }^{\circ} \mathrm{C}$. Speed parameters indicated that sperm velocity after refrigeration or deep-freezing with glycerol are lower than that for fresh semen samples. However, extenders containing GA $(3 \%)$ or EY $(10 \%)$ supported the viability of spermatozoa during freezing and thawing. Satisfactory data were obtained with the extenders containing GA (3\%) and EY (10\%).

Sperm cells diluted in high viscosity extender showed reduced swimming velocity shortly after dilution, as well as after preservation for three days at $4{ }^{\circ} \mathrm{C}$. The linearity was not significantly different, but more linear swimming sperm cells could be observed on the video screen in high viscosity extender. The percentage of progressive motile sperm increased significantly in fresh diluted samples rather than decreasing after cooling. The decrease in the velocity of fast swimming spermatozoa may be attributed to the elevated viscosity.

The higher progressive motility obtained in GA (3\%) and EY (10\%) extenders is probably due to better availability of substrate in this extender in comparison with GA (9 and 15\%) extender, a characteristic that provides greater energy support for survival and movement of spermatic cell. Changes in organization of the plasma membrane fluid mosaic can lead to alterations in permeability, functionality and metabolism of sperm cell, which may affect the motility and fertilizing ability (19).

Given that the protection mechanism of GA for 
the sperm is not known, more work to demonstrate how the GA protects sperm during freezing is sought. Another factor that may be correlated to the survival of sperm cells during storage is the amount of energy reserves contained in extender, which, in the case of exhaustion of reserves, could promote sperm metabolic death, since motility is the process that requires more energy and has a positive correlation with ATP concentrations (20).

Viscous forces dominate the motion of sperm in high viscid extenders. However, the greatly increased viscosity of diluents imposes a greatly increased resistance to progression, resulting in a very different 'meandering' waveform in mammalian cells and reduced head yaw (side-toside movement across the directional axis) (21). Despite all that, the stallion spermatozoa are able to move in high viscid extender with GA (9 and $15 \%$ ). Externally fertilizing sperm are not adapted to maintain progressive velocity in high-viscosity fluids (22). Finally, the increased viscosity results in greatly increased metabolic requirements, which may be satisfied by glycolysis $(23,24)$. Therefore, the motility of sperm in GA ( 9 and 15\%) extenders completely ceased after 72 hours of cooling. The observed low velocity of sperm in the highviscosity extender (15\% GA), evident by low VCL, VSL and VAP, should be taken into account when using diluents for artificial insemination. Moreover, a computational study (25) suggested that increasing viscosity may cause the sperm flagellum to undergo a 'buckling instability' that results in asymmetric flagellar beating and circling motility (a form of 'trapping'), without any need for asymmetric internal actuation.

Data of IMS demonstrated that the increase in the level of EY resulted in more particles or debris that could affect the accuracy of the computer-detected spermatozoa and thus expressing these particles as false spermatozoa. It has been recommended that the particulate fraction could be reduced from EY extender by sedimentation, decantation or filtration for the computer-assisted system (5).

Previous studies using EY in equine semen extenders were equivocal. Some studies $(26,27)$ showed inferiority of EY-based extenders and others $(28,29)$ showed superiority of EY-based extenders on the motility and viability at different periods of storage.

Although there was no difference in the number of normal and defective spermatozoa among extenders after cooling or freezing, it is known that cooling and freezing process promoted irreversible cellular injuries, which may impair the semen fertility.
The plasma membrane allows selective transportation of important molecules to the sperm cytoplasm and its integrity is important for the reactions necessary for union of male and female gametes (30). The superiority of GA (3\%) extender by the HOST and vital test suggested that it may give better protection to the plasma membrane during freezing. The decrease in motility and integrity of plasma membrane in GA ( 9 and 15\%) extenders may be attributed to the damage of axoneme elements and high injury rate in the plasma membrane that may compromise progressive sperm motility.

\section{CONCLUSION}

In conclusion, the present study demonstrates that the concentration of GA in a semen extender affects the viscosity and movement pattern of stallion spermatozoa, and thus the motility of the sperm. These results should be considered when ISAS systems are used to evaluate sperm motility after storage for artificial insemination. The results reported here show that GA could be used at low levels (i.e. 3\%) instead of EY in the extenders used for stallion semen chilling preservation.

\section{CONFLICT OF INTEREST}

The authors declare that they have no potential conflict of interest with respect to the authorship and/or publication of this article.

\section{ACKNOWLEDGEMENT}

The authors acknowledge the support provided by the King Abdulaziz City for Science and Technology (KACST) for funding this work through project number AT-34-71.

\section{REFERENCE}

1. Wall, R.J., Foote, R.H. (1999). Fertility of bull sperm frozen and stored in clarified egg yolk-Tris-glycerol extender. J Dairy Sci. 82, 817-21. https://doi.org/10.3168/jds.S0022-0302(99)75301-4

2. Diégo, M., Djemil B., Lamia A., Alberto N., Sandrine D., Daniel T. (2013). Preliminary results: the advantages of low-density lipoproteins for the cryopreservation of equine semen. J Equine Vet Sci. 33, 1068-1075. https://doi.org/10.1016/j.jevs.2013.04.004 
3. Kampshmidt, R.F., Mayer, D.T., Herman, H.A. (1953). Lipid and lipoprotein constituents of egg yolk in the resistance and storage of bull spermatozoa. J Dairy Sci. 36, 733-742.

https://doi.org/10.3168/jds.S0022-0302(53)91553-7

4. Van Wagtendonk-de Leeuw, A.M., Haring, R.M., Kaal-Lansbergen, L.M.T.E., Den Daas, J.H.G. (2000). Fertility results using bovine semen cryopreserved with extenders based on egg yolk and soybean extract. Theriogenology 54, 57-67.

https://doi.org/10.1016/S0093-691X(00)00324-1

5. Hirai, M., Cerbito, W.A., Wijayagunawardane, M.P.B., Braun, J., Leidl, W., Ohosak, Q.K., Matsuzawa, T., Miyazawa, K., Sato, K. (1997). The effect of viscosity of semen diluents on motility of bull spermatozoa. Theriogenology 47, 1463-1478. https://doi.org/10.1016/S0093-691X(97)00136-2

6. Vasan, S.S. (2011). Semen analysis and sperm function tests: how much to test? Indian J Urol. 27, 41-48.

https://doi.org/10.4103/0970-1591.78424

PMid:21716889 PMCid:PMC3114587

7. Mortimer, S.T., van der Horst, G., Mortimer, D. (2015). The future of computeraided sperm analysis. Asian J Androl. 17, 545-553.

https://doi.org/10.4103/1008-682X.154312

PMid:25926614 PMCid:PMC4492043

8. Turner, T.T., Reich, G.W. (1985). Cauda epididymidal sperm motility: A comparison among five species. Biol Reprod. 32, 120-128.

https://doi.org/10.1095/biolreprod32.1.120

PMid:3971006

9. Mortimer, D., Christopher, L.R., Barratt L., Bjorndahl, C., de Jager, A., Jequier, M., Charles, H.M. (2013). What should it take to describe a substance or product as 'sperm-safe'. Hum Reprod Update. 19 (Suppl 1): i1-45.

https://doi.org/10.1093/humupd/dmt008

PMid:23552271

10. Nishikawa, Y. (1975). Studies on the preservation of raw and frozen semen. J Reprod Fertil. 23, 99-104.

11. Neild, D.M., Chaves, M.G., Flores, M., Mora, N., Beconi, M., Agüero, A. (1999). Hypoosmotic test in equine spermatozoa. Theriogenology 51(4): 721-727. https://doi.org/10.1016/S0093-691X(99)00021-7

12. Hafez, E.S.E. (1993). Reproduction in Farm Animals. In: E.S.E.Hafez, Lea and Febiger (Eds.), (pp. 330-343). Philadelphia

13. Evans, G., Maxwell, W.M.C. (1987). Handling and examination semen. In: Maxwell, W.M.C. (Ed.), Salamon's Artificial Insemination of Sheep and Goat. (pp. 93-106). Butterworths, Sydney.
14. Petrie, A., Watson, P. (2002). Statistics for veterinary and animal science. Chapter 8 and 11. (pp. 90-138). Blackwell science

15. Hunter, R.H.F., Coy, P., Gadea, J., Rath, D. (2011). Considerations of viscosity in the preliminaries to mammalian fertilization. J Assist Reprod Genet. 28, 191-197. https://doi.org/10.1007/s10815-010-9531-3 PMid:21234667 PMCid:PMC3082651

16. Chian, R., Quinn, P. (2010). Cryoprotectant; In: Fertility cryopreservation. (pp. 24-38). Cambridge University Press.

17. Hyun, N., Chandsawangbhuwana, C., Zhu, Q., Shi, L.Z., Yang-Wong, C.,Berns, M.W. (2012). Effects of viscosity on sperm motility studied with optical tweezers. J Biomed Opt. 17, 1-6. https://doi.org/10.1117/1.JBO.17.2.025005 PMid:22463031

18. Suárez, S.S., Dai, X. (1992). Hyperactivation enhances mouse sperm capacity for penetrating viscoelastic media. Biol Reprod. 46, 686-691. https://doi.org/10.1095/biolreprod46.4.686 PMid:1576267

19. Amann, R.P., Graham, J.K. (1993). Spermatozoa functional. In: Mckinnon, A.O.; Voss, J.L. (Eds.) Equine reproduction. 1.ed. (pp. 715-745). Philadelphia: Lea and Febiger

20. Januskauskas, A., Rodriguez-Martinez, H. (1995). Assessment of sperm viability by measurement of ATP, membrane integrity and motility in frozen/ thawed bull semen. Acta Vet Scandnavica. 36, 571574.

21. Kirkman-Brown, J.C., Smith, D.J. (2011). Sperm motility: Is viscosity fundamental to progress? Mol Hum Reprod. 17, 539-544.

https://doi.org/10.1093/molehr/gar043 PMid:21653751

22. Woolley, D.M. (2003). Motility of spermatozoa at surfaces. Reproduction 126, 259-270. https://doi.org/10.1530/rep.0.1260259 PMid:12887282

23. Ford, W.C.L. (2006). Glycolysis and sperm motility does a spoonful of sugar help the flagellum go round. Hum Reprod Update. 112, 269 - 274. https://doi.org/10.1093/humupd/dmi053 PMid:16407453

24. Storey, B.T. (2008). Mammalian spermmetabolism oxygen and sugar, friend and foe. Int J Dev Biol. 52, 427- 437 . https://doi.org/10.1387/ijdb.072522bs PMid:18649255 
25. Gadelha, H., Gaffney, E.A., Smith, D.J., KirkmanBrown J.C. (2010). Non-linear instability in flagellar dynamics:A novel modulation mechanism in sperm migration? J R Soc Interface. 7, 1689.

https://doi.org/10.1098/rsif.2010.0136

PMid:20462879 PMCid:PMC2988265

26. Province, C.A., Amann, R.P.,Pickett, B.W., Squires, EL. (1984). Extenders for preservation of canine and equine spermatozoa at $5{ }^{\circ} \mathrm{C}$. Theriogenology 22, 409-415. https://doi.org/10.1016/0093-691X(84)90461-8

27. Bruemmer, J.E., Coy, R.C., Squires, E.L., Graham, J.K. (2002). Effect of pyruvate on the function of stallion spermatozoa stored for up to 48 hours. J Anim Sci. $80,12-18$.

https://doi.org/10.2527/2002.80112x

28. Rota, A.,Furzi, C.,Panzani, D., Camillo, F. (2004). Studies on motility and fertility of cooled stallion spermatozoa. Reprod Domest Anim. 39, 103-109. https://doi.org/10.1111/j.1439-0531.2004.00488.x PMid:15065992
29. Rota, A., Magelli, C., Panzani, D., Camillo, F. (2008). Effect of extender, centrifugation and removal of seminal plasma on cooled-preserved Amiata donkey spermatozoa. Theriogenology 69, 176-185.

https://doi.org/10.1016/j.theriogenology.2007.09.003 PMid:17945340

30. Jeyendran, R.S., Van der Ven, H.H., Perez-Pelaez, M., Crabo, B.G., Zaneveld, L.J. (1984). Development of an assay to assess the functional integrity of human sperm membrane and its relationship to other characteristics. J Reprod Fertil. 70, 219-228. https://doi.org/10.1530/jrf.0.0700219 PMid:6694140 